\title{
EDITORIAL
}

\section{CITOLOGIA ASPIRATIVA EM DOENÇAS INFECCIOSAS}

Em medicina, as doenças infecciosas constituem excelentes exemplos em que o diagnóstico rápido e preciso pode ser fundamental para obter-se uma boa resposta terapêutica. Se por um lado, grande parte deste grupo de doenças pode ser diagnosticado através dos dados obtidos pela história clínica, exame físico e exames laboratoriais (incluindo exames microbiológicos, micológicos, parasitológicos etc..), em outras situações o diagnóstico deve ser confirmado através de exames anátomo-patológicos. Não raro as doenças infecciosas podem apresentar-se como massas tumorais. Nestas situações a citologia aspirativa pode desempenhar um papel fundamental no diagnóstico.

Citologia aspirativa em um senso estrito significa um diagnóstico morfológico baseado no exame de um material que foi puncionado, aspirado, esfregado e corado. Entretanto, suas fronteiras diagnósticas ampliam-se significativamente quando a interpretação morfológica é combinada com a história clínica, exame físico e com os exames complementares. Portanto, a citologia aspirativa deve fazer parte de um sistema de diagnóstico mais do que um simples esfregaço a ser examinado ao microscópio.

Embora inicialmente relacionada ao diagnóstico de neoplasias, historicamente uma das primeiras utilizações da citologia aspirativa foi para o estudo de uma doença infecciosa. Em 1904, Grieg e Gray utilizaram a aspiração de gânglios linfáticos para o diagnóstico da tripanossomíase, em pleno coração africano ${ }^{1}$. Com a disseminação do uso da citologia aspirativa, praticamente todos os órgãos passíveis de serem envolvidos por doenças infecciosas podem ser estudados por esta técnica, sendo pulmões e gânglios linfáticos os mais comuns 2 . As linfoadenopatias constituem as situações mais freqüentes em que a citologia aspirativa é utilizada para o diagnóstico de uma doença infecciosa3. Em nossa esperiência, os fungos, tais como Paracoccidioides brasiliensis, Criptococcus neoformans, Candida spe Histoplasma capsulatum são facilmente demonstráveis em material citológico. Já nos casos de tuberculose, para além da presença de granulomas, o fundo

Recebido para publicação em 05/02/97.

\section{FINE-NEEDLE ASPIRATION CYTOLOGY IN INFECTIOUS DISEASE}

In the area of Medicine, infectious diseases constitute excellent examples where early and accurate diagnosis may be essential for obtaining a good therapeutical response. If on the one hand a great part of this group of diseases may be diagnosed through data obtained from clinical history, physical examination and laboratory tests (including microbiological, mycologic, parasitologic, and other tests), on the other hand, in other circumstances, the diagnosis has to be confirmed through anatomopathological tests.

Frequently infectious diseases may appear as tumoral masses. In such conditions, the aspirated cytology may play a fundamental role in the diagnosis.

In a strict sense, fine-needle aspiration (FNA) cytology means a morphologic diagnosis based on the examination of a material that has been punctured, aspirated, smeared and stained. However, its diagnostic limits increase significantly when the morphological interpretation is combined with clinical history, physical examination and complementary tests. Therefore, FNA cytology must constitute a part of a diagnosis system much more than a mere smear to be microscopically examined.

Although initially related to diagnosis of neoplasias, historically, one of the first uses of FNA cytology was for the study of an infectious disease. In 1904, Grieg and Gray utilized the aspiration of lymphatic ganglia for diagnosis of trypanosomiasis on the Africa highland1. With the propagation of the use of FNA cytology, almost all the organs susceptible of being envolved by infectious diseases can be studied through this technique, lungs and lymphatic ganglia being the more common ones 2 . Lymphadenopathies constitute the more frequent conditions in which FNA cytology is employed for the diagnosis of an infectious disease 3 . In our experience, the fungi such as Paracoccidioides brasiliensis, Cryptococcus neoformans, Candida sp and Histoplasma capsulatum are easily shown in cytological material. In this way, in the cases of tuberculosis, over and above the presence of granulomas, the background of the smear is frequently necrotic. In pulmonary material, the BAAR positive index in Ziehl-Nielsen stain is of about $74 \% 4$, this positivity being a lesser one when the material studied is aspirated from lymphatic ganglia. 
do esfregaço é freqüentemente necrótico. Em material pulmonar, o índice de positividade para BAAR na coloração de Ziehl-Nielsen é de cerca de $74 \% 4$, positividade esta bem menor quando se trata de material aspirado de gânglios linfáticos. Formas pseudotumorais de tuberculose, esquistossomose e de vários tipo de micoses são situações em que muitas vezes a citologia aspirativa evita uma cirurgia desnecessária. Leishmaniose também pode ser diagnosticada por citologia aspirativa e, por vezes, na coloração de Giemsa é possível identificar os microorganismos no interior de macrófagos. Em várias doenças infecciosas a demonstração do agente no material citológico não é possível ou é muito difícil, como na toxoplasmose, mononucleose infecciosa e doença de arranhadura do gato, mas nestas situações o aspecto citomorfológico aliado à clínica e aos exames subsidiários permitem um diagnóstico rápido e seguro.

O aumento do número de casos de pacientes com síndrome de imunodeficiência adquirida trouxe consigo um maior desenvolvimento da citologia aspirativa no campo das doenças infecciosas desde que os riscos deste método são muito menores do que a biópsia cirúrgica. Isto fez com que praticamente toda a adenopatia nestes pacientes pudesse ser estudada rapidamente através da citologia, sendo hiperplasias linfóides e processos infecciosos os diagnósticos mais freqüentes dos aspirados ganglionares5. Através da citologia aspirativa foi também possível o estudo de infecções oportunistas como pneumocistoses e micobacterioses atípicas.

Os riscos e complicações da citologia aspirativa são pequenos e muito pouco freqüentes como discreto sangramento, dor ou mesmo pneumotórax em punções pulmonares, mas que raramente exigem drenagem cirúrgica. O cisto hidático representa uma das situações em que os autores recomendam cautela e alguns mesmos contraindicam a aspiração quando houver uma forte suspeita clínica ou radiológica prévia deste diagnóstico ${ }^{2}$.

Muitos seriam outros exemplos de doenças infecciosas em que a citologia aspirativa poderia contribuir para o diagnóstico, mas o importante é salientar que este método rápido, simples, barato e eficaz pode e deve cada vez mais ser utilizado no domínio das doenças infecciosas pois permite diagnósticos precisos, muitas vezes etiológicos, implicando conseqüentemente em condutas mais rápidas e eficazes.
Pseudotumoral forms of tuberculosis, schistosomiasis and several kinds of mycosis are conditions where often FNA cytology prevents from an unnecessary surgery. Leishmaniasis may also be diagnosed by cytology and sometimes in Giemsa stain it is possible to identify the microorganisms in the interior of macrophage. In several infectious diseases it is either impossible or very difficult to show the agent in the cytological material as in toxoplasmosis, infectious mononucleosis and cat scratch disease, but in these situations the cytomorphological feature combined with clinical examination and supplementary tests make possible a prompt and reliable diagnosis.

The increase of the number of acquired immune deficiency syndrome patients envolved a greater development of FNA cytology in the field of infectious diseases, since the risks of this method are lesser than those of a surgical biopsy. This made possible that almost every adenopathy in these patients could be studied rapidly through the cytology. The lymphoid hyperplasias and infectious processes were the more frequent diagnoses of material aspirated from the ganglias. It was also possible to carry out, through FNA cytology, the study of oportunistic infectious such as pneumocystosis and atypical mycobacteriosis.

The risks and complications of FNA cytology are insignificant and rare such as small bloodletting, pain or pneumotorax in pulmonary punctures rarely requiring surgical drainage. The hydatid cyst represents one of the conditions where prudence is recommended by the authors. Some of them even counterindicate the puncture when a strong, either clinic or radiological, of this diagnosis is suspected 2 .

There would be many other examples of infectious diseases where FNA cytology could contribute to the diagnosis, but the important is to emphazise that this rapid, simple, cheap and effective procedure may and must be used in the field of infectious diseases, because it makes possible accurate diagnoses, often etiologic ones, thus allowing more rapid and effective procedures. 
Editorial. Schmitt FC. Citologia aspirativa em doenças infecciosas. Revista da Sociedade Brasileira de Medicina Tropical 30:177-179, 1997.

\section{REFERÊNCIAS BLIBLIOGRÁFICAS}

1. Grieg ED, Gray AC. Note one lymphatic glands in sleeping sickness. British Medical Journal 1:1252, 1904.

2. Schmitt FC. Citologia aspirativa por agulha fina: seu papel nas doenças infecciosas. Revista Âmbito Hospitalar 5:11-18, 1996.

3. Layfield LJ, Glasgow Dj, DuPuis MH. Fine needle aspiration of lymphadenopathy of suspected infectious etiology. Archives Pathology Laboratory Medicine 109:810-812, 1985.
4. Tani EM, Schmitt FC, Oliveira MLCS, Gobetti SMP, Decarlis RMS. Pulmonary cytology in tuberculosis. Acta Cirurgica 31:460-463, 1987.

5. Bottles K, McPhaul LW, Volbesding P. Fine needle aspiration biopsy of patients with the acquired immunodeficiency syndrome (AIDS): experience in outpatient clinic. Annals of Internal Medicine 108:4245, 1990.

\section{Fernando Carlos Schmitt}

Instituto de Patologia e Imunologia Molecular da

Universidade do Porto (IPATIMUP)

Porto, Portugal 